ECOLOGICA, Vol. 28, No 102 (2021), 277-282

https://doi.org/10.18485/ecologica.2021.28.102.20

Scientific paper

UDC: [347.412:339]:[616.98:578.834]

\title{
Social responsibility of trade companies during the COVID-19 pandemic
}

\section{Socijalna odgvornost trgovinskih preduzeća za vreme pandemije COVID-19}

\author{
Nenad Kojić ${ }^{1 *}$, Radmila Micić ${ }^{2}$, Maja Staletović ${ }^{3}$ \\ ${ }^{1}$ Kosovo and Metohija Academy of applied studies, Leposavić, Serbia / \\ Akademija strukovnih studija Kosovsko-metohijska, Leposavić, Srbija \\ ${ }^{2}$ University of Priština, with temporary headquarters in Kosovska Mitrovica, Faculty of Economics, Serbia / \\ Ekonomski fakultet Univerziteta u Prištini sa privremenim sedištem u Kosovskoj Mitrovici, Srbija \\ ${ }^{3}$ Business College of Applied Studies „Prof. Radomir Bojkovic, PhD", Kruševac, Serbia / \\ Visoka poslovna škola strukovnih studija „Prof. dr Radomir Bojković“, Kruševac, Srbija \\ ${ }^{*}$ Corresponding author / Autor za prepisku
}

Received / Rad primljen: 17.12.2020, Accepted / Rad prihvaćen: 15.05.2021.

\begin{abstract}
The presence of coronavirus illustrate one of the most significant changes in the modern environment, that might cause serious consequences in economic, social and other civic implication. Some of them are already visible in the trade sector. The economic consequences, which are reflected in the closure of a large number of stores, layoffs, reduction of wages, shortening of working hours, declining demand for goods, at some point, place the initiative of business companies to act in line with the concept of sustainable development out of the spotlight. On the other hand, the crisis caused by the corona virus pandemic has a significant impact on consumers, their habits, expectations and shopping opportunities. In view of the fact that consumers are significantly interested in socially responsible companies, the aim of this research is to determine consumers attitudes towards social responsibility of trade companies during the coronary virus pandemic. For the realization of the research and in order to collect necessary data, the unique questionnaire was constructed.
\end{abstract}

Keywords: corona virus, changes, social responsibility, consumer, trade companies.

Sažetak: Prisustvo korona virusa predstavlja jednu od najznačajnijih promena savremenog okruženja za koju se predviđa niz ekonomskih, socijalnih ali i drugih opštedruštvenih posledica. Neke od njih su već očigledne i u sektoru trgovine. Ekonomske posledice koje se ogledaju u zatvaranju velikog broja trgovinskih objekata, otpuštanju radnika, smanjenju plata, skraćivanju radnog vremena, smanjenoj potražnji za robom, donekle u drugi plan stavljaju inicijative za poslovanje trgovinskih preduzeća u skladu sa konceptom održivog razvoja. Sa druge strane, kriza izazvana pandemijom korona virusa ima značajan uticaj i na potrošače, njihove navike, očekivanja i mogućnosti kupovine. S obzirom da je poznato da su potrošači u značajnoj meri zainteresovani za društveno odgovorno ponašanje preduzeća, cilj istraživanja je utvrđivanje stavova potrošača o socijalnoj odgovornosti trgovinskih preduzeća tokom pandemije korona virusa. Zarad realizacije istraživanja konstruisan je originalan upitnik pomoću kojeg su prikupljeni neophodni podaci.

Ključne reči: korona virus, promene, socijalna odgovornost, potrošač, trgovinska preduzeća.

10rcid.org/0000-0001-5399-8132, e-mail: nenad.kojic@akademijakm.edu.rs

${ }^{2}$ orcid.org/0000-0003-3562-1459, e-mail: radmila.micic@pr.ac.rs

${ }^{3}$ orcid.org/0000-0002-2903-498X, e-mail: dajicmaja5@gmail.com 


\section{INTRODUCTION}

Knowing that the success of a company is measured not only by good business results but also by the attitude towards the society and the surroundings in which it operates, a question arises whether the trading companies operate in accordance with the rules of sustainable development concept during the coronavirus pandemic situation. The new situation with the coronavirus has significantly altered the former way of functioning of many trading companies. Namely, due to the application of preventive measures aiming to prevent the spread of coronavirus during last, but also this year, as well, numerous trade facilities were closed for a certain period, except for those selling food products and hygienic supplies.

Additionally, all trading companies are obliged to create safe working conditions as well as safe conditions for consumers in the facilities. On the other hand, driven by the fear and uncertainty for their safety, consumers have significantly changed their spending habits, but the question also arises whether they have changed their attitude towards the need for a socially responsible operation of companies. For that reason, the subject of this research is to examine the attitudes of consumers when it comes to the social responsibility of trading companies during the coronavirus pandemic situation.

\section{PURCHASE „UNDER SPECIAL SAFETY MEASURES"}

The coronavirus pandemic is an entirely new form of crisis that no country has faced so far, so it is not possible to expect the solvation of the problems and overcoming the negative consequences that affected the economy and society as a whole on short notice (Marjanovic, Djukic, 2020). Regardless of the appearance of the coronavirus vaccine, it is still uncertain when will the economic recovery begin and how long it will last. You could say that, apart from the year 2020, the year 2021 will also be extremely difficult and uncertain in all aspects. The quarantine which most people on this planet experienced has diminished economic activity as expected, and the demand and supply ratio has decreased across the world (Ceha, Ceha, 2020). Without a doubt, the coronavirus pandemic has changed many aspects of our lives (Pan, Zhang, 2020). Similarly, after the spread of this virus, our trading habits have significantly changed, so we can often encounter the term purchase "under special safety measures". Namely, on March 11th, 2020, all employers and employees in the Republic of Serbia had access to the Directions with recommendations and pieces of advice about taking preventive measures that are in the function of preventing the spread of coronavirus (Instruction, 2020). The measures for minimizing the effects of the coronavirus taken by the countries and their health systems were to reduce the mortality rates and the frequency of virus transmission among the population (Radic et al, 2020). In the trading area, the key measures were wearing protective masks, more frequent hand disinfection, limitation of working hours, limitation of the number of people in trade facilities depending on the size of the facility, mandatory 2-meter social distance, intensified disinfection of trading facilities. The coronavirus pandemic has directly conditioned the change in the behavior of the consumers in the purchasing process with the necessary safety measures. According to the research that was conducted by the Marketplace and public opinion agency (MASMI) in late April 2020, half of the working-age population was affected by the pandemic in some way, while every one out of five citizens was under impression that they were in a difficult financial situation (MASMI, 2020). Perhaps that is one of the reasons why certain consumers are very indignant at the whole situation and are, therefore often confronting the introduced measures, especially when it comes to wearing protective masks, which often leads to unpleasant situations for workers when they need to warn such consumers.

On the other hand, most of the consumers have accepted life with coronavirus as a new norm, and are therefore doing their best to adapt to it. It should also be noted that due to the whole coronavirus situation, many consumers avoided shopping last year. According to the data of the Republic Institute of Statistics in the middle of $2020,36,1 \%$ of Internet users have purchased, i.e., ordered goods or services via the internet, compared to $34,2 \%$ of Internet users in 2019. (RIS, 2020). It can be said that many introduced restrictions and appeals for the applications of all the social distancing measures have instigated the growth of online purchases to some extent. In his work, Vasic talks about many authors around the world dealing with the effect of coronavirus on the rapid digitalization of our society and that the sector of online purchase and delivery is one of the sectors that have reacted the fastest and reached high profitability (Vasic, 2020). Online purchase has now become the rule for many customers that have avoided that way of purchase in the past (Vasic, 2020). However, regardless of the new coronavirus situation, we should not neglect the need for and significance of the operation of the trading companies following the concept of sustainable development and social responsibility. Having in mind that certain 
authors consider the trading sector to have reacted well to the need for rapid digitalization of our society on one hand, but on the other hand, there are economic consequences seen in closing a large number of trading facilities, layoffs, reduced salaries, and similar, a question arises whether and to what extent are the trading companies responsible towards consumers and society as a whole during the existence of coronavirus.

\section{MATERIALS AND METHODS}

The potentials for the socially responsible operation of trading companies are different even in the conditions of coronavirus pandemic. We will now provide several examples from practice: providing the opportunity of free delivery (market Oaza in Krusevac); installations of transparent plexiglass partitions with the purpose to reduce direct contact between employees and consumers, aiming to protect employees and consumers from coronavirus (trade companies: Dis, Roda, Idea, etc.); providing support to the employees as a form of gratitude for additional commitment (trading company dm drogerie); support for the community and healthcare system through securing medical equipment (trading companies such as Lidl, PS fashion, Delez Serbia); education of consumers about the needs of undertaking protective coronavirus measures (trading company Roda); raising funds to help children who were infected (3$\mathrm{M}$ market plus), and similar.

Motivated by the fact that consumers highly respect and support socially responsible companies we have conducted research to determine the attitudes of consumers about the social responsibility of trading companies during coronavirus pandemic. The research was conducted in March 2021, on a sample of 70 respondents, by surveying consumers in a trading company 3-M market plus, in Krusevac. For research realization, we have constructed a specialized questionnaire, which besides the general questions also contains questions about the attitudes of consumers about the coronavirus and social responsibility of trading companies. The questionnaire consists of 12 questions. To provide a more precise presentation of this topic we have used the following methods: observation, analysis, synthesis, descriptive method, and method of comparison. The obtained results will be presented numerically and graphically and qualitatively described in this work.

\section{RESULTS AND DISCUSSION}

In this research, the respondents were divided into categories according to age and gender structures (table 1). In the given sample, there were
$29 \%$ of employed and $34 \%$ of unemployed persons, whereas the rest of the sample consisted of students $(21 \%)$ and retirees $(16 \%)$.

Table 1 - Distribution of respondents by age structure and gender

\begin{tabular}{|l|c|c|}
\hline \multirow{2}{*}{$\begin{array}{c}\text { Age } \\
\text { structure }\end{array}$} & \multicolumn{2}{|c|}{ Gender } \\
\cline { 2 - 3 } & Male & Females \\
\hline From 18 to 30 & 10 & 10 \\
\hline From 31 to 40 & 13 & 11 \\
\hline From 41 to 50 & 6 & 9 \\
\hline Over 50 & 4 & 7 \\
\hline In total & 33 & 37 \\
\hline Percentage & $47 \%$ & $53 \%$ \\
\hline
\end{tabular}

Source: authors based on research

With its appearance, the coronavirus pandemic has significantly altered people's lives and contributed to the development of fear of being infected with the virus, job loss, rising cost of living, and similar. Thus, it came as no surprise that $54 \%$ of respondents gave a confirmative response to the question of whether they were afraid of coronavirus (graph 1).

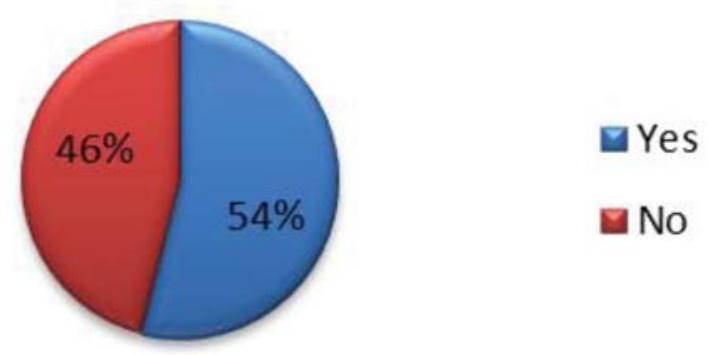

Graph 1 - The respondents 'attitudes towards the fear of coronavirus Source: authors

A sense of fear has caused significant changes in the behavior of consumers while shopping. As a measure of protection against the coronavirus, the following was recommended: wearing a mask, social distancing, and hand disinfection, wearing disposable gloves, using the service of cashless payment. Our research has shown that, in the given example, $76 \%$ of consumers always adhere to the prescribed measures while visiting trading objects (graph 2).

Lockdown and social distancing to fight against coronavirus have created significant behavior disorders of the consumers (Sheth, 2020). Soon after the appearance of the virus, there was frantic shopping of protective masks, disinfectants, wet 
wipes, toilet paper, soaps, but also basic life groceries such as flour, oil, and sugar. This way of behavior has made certain trading objects limit the number of groceries and other supplies that one consumer could buy at once. However, when asked whether they were buying stocks of flour, oil, sugar, and other groceries, only $13 \%$ of the respondents confirmed, but $70 \%$ of the respondents believe that there is no need for such purchase (graph 3 ).

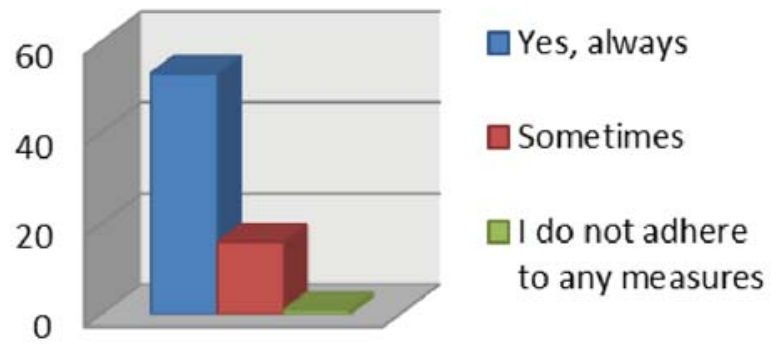

Graph 2 - Respondents`attitudes towards adhering to the prescribed measures (wearing a mask, social distancing, hand disinfection) while visiting a trading object (Source: authors)
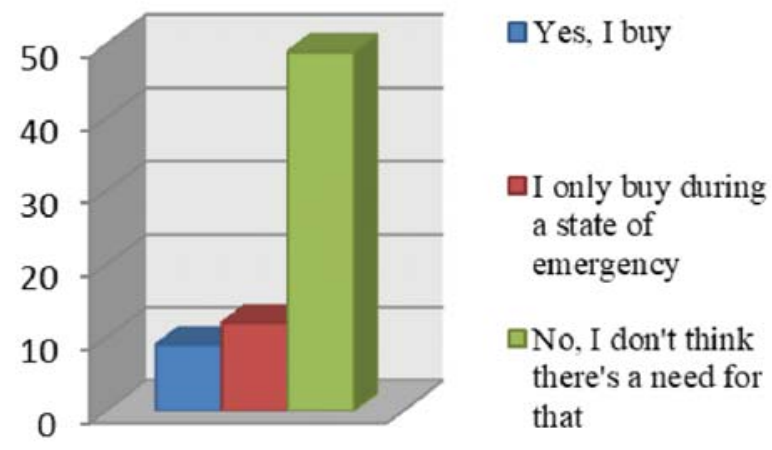

Graph 3 - Respondents' attitudes towards shopping stocks of flour, oil, sugar, and other groceries during the coronavirus pandemic. Source: Authors

Customer care today is not reflected in classic marketing campaigns or attempts to overtake the competition and take the best position on the market. Instead, it is reflected in true and honest providing support, that is visible, authentic, honest, and has a direct impact on the consumer (Consumer expectations, 2020). For this reason, it is expected from every trading company to take care of the consumers ' health, making safe conditions for their stay in trading facilities. According to our research, $70 \%$ of the respondents believe that trading objects are undertaking all the prescribed measures to protect consumers from the coronavirus (graph 4).

The education of consumers about the need to undertake preventive measures to prevent the infection and spread of coronavirus today represents an extremely important activity of trading companies. In the given sample, $59 \%$ of the respondents believe that trading companies are undertaking certain actions to educate a consumer about the need for undertaking protective measures against coronavirus. (graph 5).

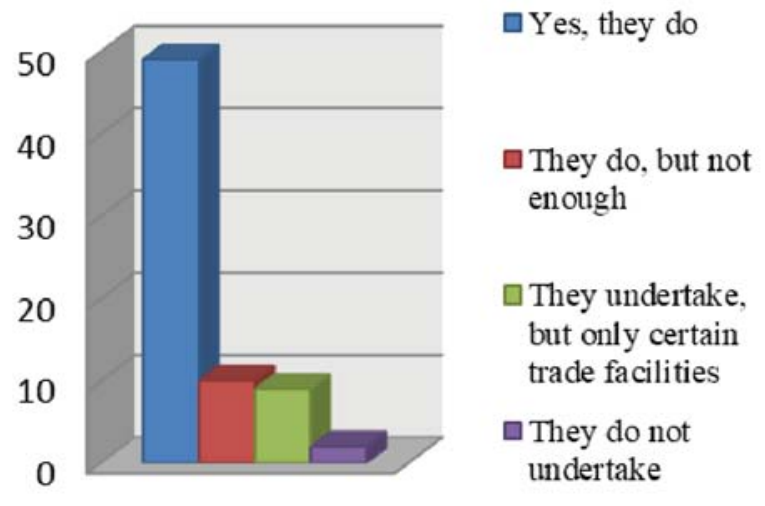

Graph 4 - Respondents` attitudes about whether trading objects are undertaking all the prescribed measures to protect consumers from coronavirus. Source: Authors.

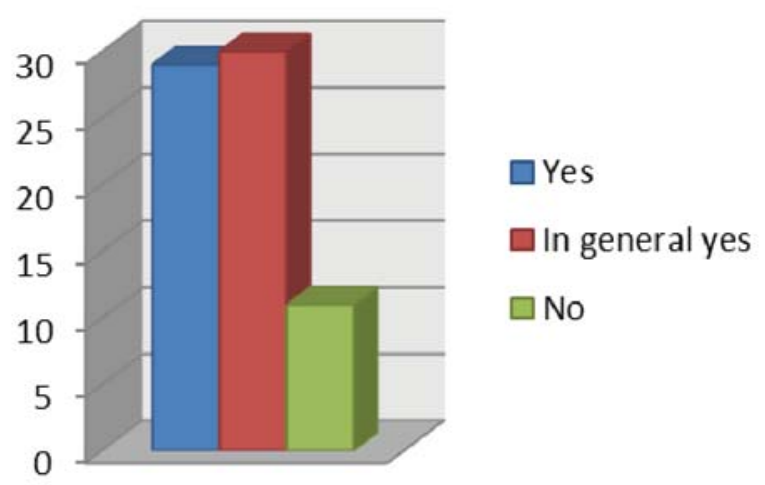

Graph 5 - Respondents' attitudes about whether trading companies are educating consumers about the need for underrating coronavirus protective measures (Source: Authors)

Just some of the ways in which it is possible to raise people's awareness of the coronavirus are visible rules of behavior when entering the trading facility, installation of disinfection barriers at the entrance, wearing protective masks and gloves by the employees (thus setting an example of how consumers should behave), a call for responsible behavior through sites, advertisements, and so on. In this way, trading companies show one way of social responsibility, when the most needed thing is to be active in this field. The research suggests that $43 \%$ of respondents believe that trading companies provide greater support to the social community during the coronavirus pandemic (graph 6), and this 
is done, in their opinion, through different discounts, friendly attitude to the consumers, care for their employees, providing help to medical staff and similar.

With the introduction of protective measures against coronavirus, the economic activity has slowed down, and in some sectors completely stopped, which had a direct impact on the unemployment rate, higher allocations for social help, and the reduced purchasing power (Martin, 2020). Trading facilities who are selling groceries, but also those with developed opportunity for Internet sale, did not feel the crisis to a great extent, and even noticed a certain increase in sales. However, even though online sale marks quantum leaps in the whole world (Consumer expectations, 2020), our research has shown that among the respondents, the awareness of the Internet sale advantages is not highly developed yet. Only $21 \%$ of the respondents shop via Internet, while most of them (52\%) still do not trust this type of sales (graph 7).

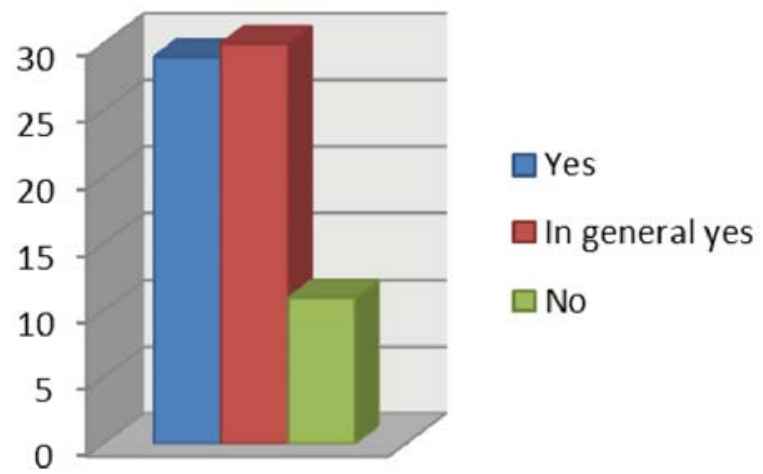

Graph 6 - Respondents`attitudes about whether trading companies offer greater support to the social community during the coronavirus pandemic. Source: Authors

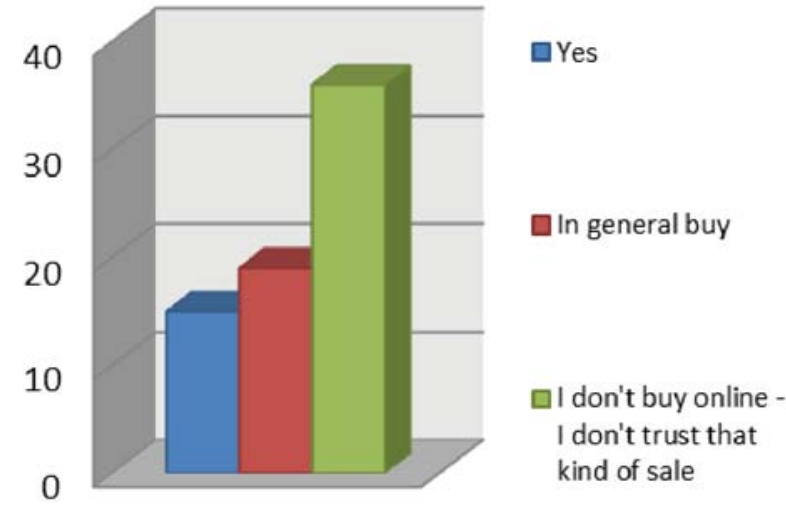

Graph 7 - Respondents`attitudes towards online shopping during the coronavirus pandemic. Source: Authors.
The companies selling their products in this way must behave responsibly towards their customers. They can achieve this by offering their products at a lower price (as is the case with trading company Shoes Metro), or by respecting the deadlines for product delivery, product quality, and similar.

However, our research shows that currently the consumers are not concerned by the social responsibility of trading consumers to a great extent. What concerns them the most is the health of their loved ones ( $45 \%$ of the respondents), rising living costs (35\% of the respondents), while reduced salaries are the biggest concern for the $9 \%$ of the respondents.

\section{CONCLUSION}

It can be concluded that during coronavirus pandemic situation the opportunities for socially responsible behavior of trading companies are different and that in most cases are following the current situation. A certain number of trading companies, operating in the city of Krusevac offer support to health institutions and the social community in the fight against the coronavirus through different donations. It can be said that today, one of the markers of socially responsible behavior of trading companies, among other things, is adhering to all the prescribed measures of protection against the coronavirus. Namely, if trading companies create safe working conditions as well as safe conditions for their consumers in trading facilities, they behave responsibly towards their employees and consumers as well.

The occasional closure of stores had a major impact on the increase of Internet sales, and large and successful trading companies that already own their sites on the Internet did best. Thus, it can be concluded that these trading companies (especially in the field of food sales) have greater potential for socially responsible activities during the coronavirus pandemic.

\section{REFERENCES}

[1] Marjanovic, D., Djukic, M. (2020), Economic mitigation measures COVID-19, In: Black swan in the world economy 2020. Institute of Economic Sciences, Belgrade, pp. 91105. http://ebooks.ien.bg.ac.rs/1490/ accessed on: 20.05.2021. (in Serbian).

[2] Ceha, N., Ceha, M. (2020), Fiscal policy measures in the period of coronavirus, Business trends, 16(2), 9-17.

[3] Pan, S. L., \& Zhang, S. (2020), From fighting COVID-19 pandemic to tackling sustainable development goals: An opportunity for responsible information systems research, Internati- 
onal Journal of Information Management, 55, doi.org/10.1016/j.ijinfomgt.2020.102196.

[4] Instruction, (2020): Instruction on prevention and protection measures for coronavirus COVID-19, https://www.propisi.net/uputstvo-omerama-prevencije-i-mere-zastite-za-koronavirus-covid-19/, accessed on: 08.03.2021. (in Serbian).

[5] Radic, V., Radic, N., Ravic, N. (2020), The impact of the corona virus pandemic on the goals of sustainable development and the economy, Ecologica, 27(99), 366-375 (in Serbian).

[6] MASMI, (2020): Market and Public Opinion Research Agency, https://masmi.rs/vesti/zivoti-kriza-efekti-pandemije/, accessed on: 18.03 . 2021. (in Serbian)

[7] RIS, (2020): Republic Institute of Statistics, https://www.stat.gov.rs/sr-latn/vesti/20200922upotreba-ikt-a-pojedinci-2020/?s=2702 i https://www.stat.gov.rs/sr-latn/vesti/20190920godisnje-istrazivanje-o-ikt/?a=27\&s, accessed on: 20.03.2021. (in Serbian).

[8] Vasic, V. (2020), 24/7 digitalisation as a response to turbulent events, Bankarstvo, 49(1), 4-7 (in Serbian).

[9] Sheth, J. (2020), Impact of Covid-19 on consumer behavior: Will the old habits return or die?, Journal of Business Research, 117, 280-283.

[10] Consumer expectations, (2020): Consumer expectations at the time of the corona, https://www.instore.rs/koronavirus/velikaocekivanja-potrosaca-u-doba-korone10561.html, accessed on: 26.03.2021. (in Serbian).

[11] Martin, V. (2020), The response of the monetary and fiscal policies on COVID 19-in Serbia, Bankarstvo, 49(2), 2020, 70-114 (in Serbian). 